\title{
Sounding Shakespeare: An Interdisciplinary Educational Design Project in English
} and Music

\author{
Marthe Sofie Pande-Rolfsen, Norwegian University of Science and Technology \\ Anne-Lise Heide, Norwegian University of Science and Technology
}

In Norwegian primary and secondary education, pupils start learning English from the first grade, but they will often not encounter Shakespeare's texts until later grades, if at all. The pupils' experience with Shakespeare relies heavily on the teacher's acquaintance with his work. Many teachers might consider Shakespeare outdated and irrelevant for today's modern classrooms, but in the context of EFL (English as a Foreign Language) classrooms there are several reasons for why we should work with and learn about Shakespeare's texts. Winston and Tandy write that "Shakespeare's plays are not just good, entertaining stories told in beautiful language; like the best kind of stories, they make us think about important issues that never go away because they are about what makes us human" (4). Shakespeare also provides an important cultural, textual and linguistic foundation (Gibson; Winston and Tandy). If pupils are to encounter Shakespeare in school, then student teachers should experience ways of working with Shakespeare during their teacher training as well. A way for pupils to discover, explore and experience Shakespeare's texts is through music, which can provide pupils with an active learning process through performance and bodily and aesthetic experiences.

It is important to take an active approach when teaching Shakespeare, especially in the EFL context where active methods not only engage with pupils' imagination, but also involve them in speaking the target language (Matz and Rogge). Matz and Rogge note that such active approaches "allow students to develop their own understanding, access and interpretation of Shakespeare, his time and his works" (315). In light of this, we have developed the Sounding Shakespeare project, an interdisciplinary education design project for student teachers in a Norwegian teacher education program. Music and English (as a Foreign Language) were the disciplines involved in the project in which emphasis was placed on the student teachers' experiences of working with Shakespeare through active, creative and aesthetic processes. According to Gibson, "Active methods release students' imagination and involve them in 
speaking and acting. [...] It helps them to make Shakespeare their own, as they inhabit the imaginative worlds of the plays through action" (xii). In the Sounding Shakespeare project, the students transformed text into both verbal and musical soundscapes before writing a graphic score and creating a performance together. This allowed students to be actively involved in both experiencing Shakespeare's work, and simultaneously take part in experiencing musical composition and improvisation.

Our main research question was: How can interdisciplinary approaches in English and Music contribute to meaningful experiences of Shakespeare's texts? Based on this we have focused our study on the following questions:

- How do students experience working with Shakespeare's text?

- How do students experience creating music through Shakespeare's text?

- How do students experience interdisciplinary work through aesthetic processes?

These questions became the guiding principles for the design of the learning sequences for the two workshops in which excerpts from A Midsummer Night's Dream were used as the foundational texts.

\section{The Sounding Shakespeare Project}

\section{Research Design}

We designed learning sequences for the project that included research workshops for the participants. As researchers, we have therefore functioned as designers (in advance), and as teachers (during the workshops). Participants in the study were student teachers from a primary and lower secondary teacher education program in Norway, who were either in their third or fourth year of their subject disciplines. Some were English students, some music students and others studied performing arts. Taking part in this research project was voluntary and the research workshops took place outside of the students' on-going studies. There were 12 participants in the research workshops.

We chose to use two short excerpts from A Midsummer Night's Dream. The first excerpt was from Act 2 Scene 1 (lines 1-15), in which Puck greets a fairy in the woods asking them where they are going, "how now, spirit; whither wander you?" (2.1.1), for which the fairy answers in descriptive ways of all the places in the woods they wander and what they do there: "I 
serve the Fairy Queen, / To dew her orbs upon the green" (2.1.8-9). For the second workshop, participants were given an excerpt from the same act and scene with Oberon's speech to Puck (lines 249-258). In this passage, Oberon describes the place where Titania sleeps and what he intends to do: "I know a bank where the wild thyme blows, / Where oxlips and the nodding violet grows" (2.1.249-250), "And with the juice of this I'll streak her eyes, / And make her full of hateful fantasies" (2.1.257-258).

We chose excerpts that included rhyming couplets but that were not written as songs in the original play. Both passages include dialogue between characters and vivid imagery, which we hoped could inspire musical imagery and language play. Although the language is often playful in these passages, some parts also include tension and these contrasting elements provided an opening for exploration of the text through speech and music composition.

\section{The Workshop Design of Sounding Shakespeare}

For the workshops, the participants were organized into group A and group B, regardless of subject, and both groups participated in workshop 1 and workshop 2. The workshops were organized as follows:

\begin{tabular}{|l|l|l|l|l|}
\hline & Group A & Group B & Rehearsal A\&B & Video recording \\
\hline Workshop 1 & $\begin{array}{l}\text { Speech } \\
\text { Composition }\end{array}$ & $\begin{array}{l}\text { Music } \\
\text { Composition }\end{array}$ & 30 minutes & Performance \\
$\begin{array}{l}\text { Learning activity with } \\
\text { instructions, teacher-led }\end{array}$ & Music Composition & $\begin{array}{l}\text { Speech } \\
\text { Composition }\end{array}$ & 0 minutes & 1,40 minutes \\
\hline $\begin{array}{l}\text { Workshop 2 } \\
\text { 40min. }\end{array}$ & $\begin{array}{l}\text { Happening } \\
\text { Open learning activity, } \\
\text { no teacher guidance }\end{array}$ & & & 1,14 minutes \\
\hline
\end{tabular}

The workshop design was in line with the subjects of English and Music and included elements from both school subjects' national curricula in Norway. From the English subject, the focus was on Shakespeare as the literary text. This is a part of the subject's main area of Culture, Society and Literature where pupils should encounter a variety of English literary texts (The Norwegian 
Directorate for Education and Training, English Subject Curriculum). The workshops also included language specific components such as exploring and playing with prosody including intonation, volume, pitch and rhythm. It is important to note that the workshop itself was not about teaching prosody to students, but rather to let them engage with and play with the prosodic elements of the text. These elements were mentioned to the participants, but not measured in any way. The aim was to explore the text in actively, musically and aesthetically by composing a speech composition which would be performed. In relation to Music, the main subject area of composing was the focus, where pupils should be able to both experience and create music (The Norwegian Directorate for Education and Training, Curriculum in Music). Project participants composed music by experimenting with different instruments, such as piano, guitars, bass, woodand brass instruments and different percussion instruments, and by noting down the composition as a graphic score, which is a visual form of musical notation with signs and drawings. We decided to provide students with two different experiences in the two workshops, one that was teacher-led, and another which was more open with no guidance at all. The reason was to compare the students' experiences of the processes and their final performances. In the following we present the workshops, designed for music and language, in more detail. The groups worked separately before they met. One teacher led and observed each workshop.

\section{Workshop 1: Music}

The assignment was to compose music for the text, and participants were encouraged to describe the mood of the entire text through music focusing on the beginning, the highlights, and the ending. Furthermore, they were instructed to divide the text into sequences and find inspiration through expressive phrases and words. They could use any instrument, play with traditional or untraditional techniques, and compose in major or minor tonality or atonality. The completed composition should then be written down as a graphic score. To help them get started, I offered some compositional tips such as using repetitive motifs and soundscapes, describing the text or mood with music, and using the rhythm of the text as inspiration.

\section{Workshop 1: Language}

For the language part of the workshop, we experimented with reading the text aloud and exploring its musical features, such as intonation, rhythm, tone of voice, volume, stress and 
length (of syllables). This is a form of "active reading," a familiar technique used for reading the text aloud as one voice. Here, the emphasis is on the text being performed by the group. As the instructor, I had already prepared a Speech Composition for the first workshop by writing a musical score for the students. In this composition, I had decided how the text should sound, but there was room for the students to provide thoughts and commentary throughout, making changes where they felt needed. Some parts of the texts became solos, and other sentences were spoken together as a choir. Here is an example from the score:

Ekko 2 grupper: (pp) Over hill (over hill), (p) over dale (over dale),

(f) Thorough bush (thorough bush), (ff) thorough fire (thorough fire);

In this example, participants repeated words as an echo,, beginning with a low volume (in pianissimo), increasing gradually as the text develops. My initial approach to the textual score was to allow the students to play with the text as much as possible by incorporating opportunities into the score that would allow the students a range of ways to speak (or sing) the text. Sometimes I would specify if they were to speak the text with a specific emotion (i.e. happy), which would affect the way the students said the sentence. Further, as the example below shows, by adding instructions for a specific pitch (here with a glissando, which is falling downwards from high pitch to low), we mirrored the image being presented in the text (a moon) with the sound, gliding from high to low, sounding out the spherical shape of the moon. These were conscious choices made by me as the instructor.

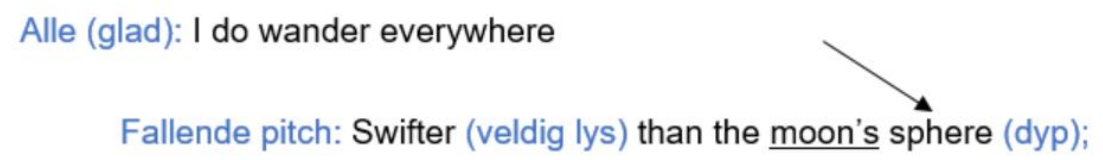

\section{Workshop 1: Performance}

In the last part of the workshop, groups A and B presented their compositions to each other. Then they were given time to collaborate and rehearse for a Performance using the two compositions to create a cohesive whole. Performance is here defined as an artform where music and lyrics merge into an expression that is partly planned and partly improvised. 


\section{Workshop 2: Music}

In workshop 2, I gave the participants a more open task and asked them to compose without any guidance from the teacher. They could choose whichever instruments they wanted to use, and they were free to use musical tools and expressions. The whole composition should be noted down as a graphic score.

\section{Workshop 2: Language}

The second group was given the task to write a score of their own and create a Speech Composition. As the instructor, I did not interfere or give any guidance. They were, however, given a list of elements they could consider when composing (in relation to for example tempo, volume and pitch, as well as how they could read it: adding solo parts, echo and so forth).

\section{Workshop 2: Happening}

In the Happening the groups did not get any time to work on the two compositions together before performing. Happening is here defined as an event that combines elements from the art forms of music and lyrics and to stage them as a live action ("Happening" Britannica Academic). Neither groups knew what the others had created, but they still performed their work as one, at the same time and on the same stage. With no rehearsal, the Happening in workshop 2 had a more spontaneous and improvised form than the Performance in Workshop 1.

\section{Theoretical Foundation}

\section{Educational Design Research (EDR)}

One of our aims for the Sounding Shakespeare project is to develop new approaches to teaching and learning within teacher training through educational design research. Our design focuses on creative and aesthetic learning processes which aim to decrease the fear factor of using Shakespeare in the classroom, and to provide the students with an experience of interdisciplinary work and aesthetic learning processes. When talking about a design for learning, Selander writes that this educational practice is about studying learning as well as "contributing to the discussions about how learning and teaching can change and how new, meaningful connections can be created" (133, our translation). EDR emphasises the creation of new meaningful connections, as well as creating new gateways for interpretations (Selander 125). From this 
perspective, the aim is to contribute to the students' future teaching careers, and a designoriented practice entails understanding learning as "processing, transformation and reproducing knowledge expressions" (134, our translation). According to McKenney and Reeves, EDR is different from other forms of inquiry, since it attends to "both solving problems by putting knowledge to use, and through that process, generate new knowledge" (133). We plan to take our findings from this project and continue to develop new ways of working with Shakespeare across subjects.

Educational design research normally entails three phases: i) analysis/orientation, ii) design and development, and iii) evaluation and retrospection (McKenney and Reeves). These phases can be revisited throughout the project. For the Sounding Shakespeare project, we began by designing a pilot project which was executed in 2017 with student teachers of English and Music. When evaluating the pilot, we found that the component most in focus had been the music composition, and we therefore wanted the project to also entail a speech composition for the design to be more interdisciplinary. Therefore, we revisited our workshop design and developed two new workshops where music, language and text played an important role within both workshops. This article presents findings from our main research workshop only.

\section{Text and Meaning-Making}

In Shakespeare's texts, language is often seen as challenging, especially in an EFL context. According to Crystal, we can struggle to understand for many reasons, since linguistic difficulty can be caused by unfamiliar vocabulary, grammar, spelling and punctuation. However, the fact remains that only $10 \%$ of Shakespeare's grammar "is likely to cause a comprehension problem" (Crystal 12). Furthermore, Crystal reminds us that we must draw a distinction between “difficulty of language and difficulty of thought" (11) with Shakespeare's vocabulary. He continues to write that "[s]imple language can express a complex thought $[\ldots]$. Conversely, complex language can express simple thought" (11). It is crucial to balance the need (or wish) to understand the literal meaning in each word of Shakespeare's text (using, for example, a translation or a modernized version), and to make room for the imagery, rhythm and rhyme to guide our experience of the text instead, which in turn can help us find meaning. When reading or studying Shakespeare, Stredder notes that commentaries and study guides are often set out to give "right answers", but he highlights that "the most secure learning, and the learning that has 
the most lasting educational value, build on students' personal experience of reading the text for themselves" (244). This also becomes the starting point for our exploration of the text with students in the Sounding Shakespeare project, where the aim is not to reach a "right answer" or figure out what the text means (literally or symbolically), but to explore and experience the text and the way it sounds, moves, surprises and how it can come alive in the reading itself.

\section{Music and Language}

There are many known benefits to working with music in language education, and multiple studies within several research fields show how music and language are closely related, for example within cultural studies, cognitive science and language acquisition (Engh). Within the field of cognitive science, it is suggested that the "musical structure is processed in language areas of the brain" (Engh 116). Since both music and language are processed in the same region, “our brains may recognize aspects of linguistic and musical sequences in a similar matter" (Engh 116). Other studies (such as Koelsch; Patel) show how our brains are formed to better receive and treat language sounds when we are working with music.

Similarities and differences in music and language are also discussed by scholars in music psychology. According to Bonde, "Music and language can be inextricably linked to each other, but they can also be two completely separate channels for expression and communication" (102, our translation). To illustrate the similarities between the two disciplines when it comes to behavioural and formal aspects, Sloboda has developed a model showing how both music and language consist of three components: phonology, syntax and semantics (Exploring the Musical Mind 177). The parallels with music and language are obvious, because the phonemes in music are the tones that can be characterized by frequency or pitch, overtones and duration. In relation to syntax, Sloboda shows how language follows grammatical rules by putting phonemes together to make words and meaningful sentences. He points out that we find this in music as well, which also follows rules for how components are put together into a musical structure (179). Lastly, we have the semantic level, which in language is about the meaning of words and sentences, and that these components always refer to "something". Music, however, does not refer to "something" in the same way as words and sentences do, but Sloboda points out that music still has "extramusical meaning" (The Musical Mind 59). He suggests that meaning might occur when the music "employs mimicry to considerable effect" (59) (such as when violins play glissandi to 
create a howling storm), or when "music employs symbolic reference to an extra-musical event" (59). These are just a few examples of meaning-making in music, and in this way, music also includes a semantic level, as language does. Our project is concerned with how music can help create a more meaningful learning experience, as well as exploring and experimenting with new ways of working across these subjects through aesthetic and bodily processes.

\section{Aesthetic and Bodily Learning Processes}

Experience is central to the Sounding Shakespeare project; this is especially related to learning through aesthetic and bodily processes. In the project, these processes took place when students worked with music and speech composition and devised or improvised performances together. These were creative, active and aesthetic experiences. Aesthetics is an arts theory, but it also has an anthropological context where what humans experience as important is studied, and how "knowledge [...] is created through the senses, a sensory- and emotional recognition" (Sæbø 107, our translation). According to Sæbø, aesthetic learning processes presuppose the following:

[That] our bodily senses (sight, smell, hearing, taste and touch), the affective (emotional encounters and experiences), and the body (bodily-kinaesthetic encounters and experiences from when our body is used in active engagement) are woven into the cognitive (our imagination, fantasy and thought) in an art-based experiential learning process (108, our translation).

Through arts-based activities, work is often practical, bodily and affective at the same time. In the book Dybde//Laring, Dahl and Østern look at bodily learning in connection with cognitive learning and experiences. They write that "actions are affective and emotionally anchored, and the cognitive develops through intra-action with the affective" (50). As stated by Dahl and Østern, bodily learning sees movement, thinking and affect as parallel activities, and all of these are activated in bodily learning processes. This is connected to the ideas of Merleau-Ponty related to the experience of the body, where he states that one must experience something in order to understand it (188). To experience with the body means to sense, to touch, to smell, to feel, and those are the bodily experiences we keep in our memories. 
Bodily experiences are important to education and learning. Stoltz writes that "As human beings we do experience the world as meaningful in relation to our individual projects, but this meaning is not something we 'construct' from sensory input, on the contrary it is an essential part of the world perceived or experienced" (479). Further, he notes that the way we successfully understand something is by experiencing it. The experience is also important in MerleauPonty's philosophy, and the experience is central to our project as well. As Stoltz writes, "since 'real' human experience is subjective and full of meaning the ramification for how we come to learn is significant, particularly how we learn through our embodiment" (481). Bodily learning involves engaging with the world as a "being-in-the-world" (Stoltz 483), and through embodiment we make sense of the world in a meaningful way. Meaning is thus tightly bound to our bodily experiences.

Active, creative and aesthetic experiences are also related to the current curriculum changes taking place in Norway (Fagfornyelsen) where one of the subsections to the Core Curriculum is "the joy of creating, engagement and the urge to explore" (Core Curriculum: values and principles for primary and secondary education). This section states that " $[\mathrm{t}] \mathrm{he}$ school must respect and nurture different ways of exploring and creating. The pupils must learn and develop through sensory perceptions and thinking, aesthetic forms of expressions and practical activities" (9). Not only are these ideas present in the national curriculum, but it is also clearly stated in the new framework plan for Primary and Lower Secondary Teacher Education, where student teachers should be able to create inclusive learning environments that contribute to better academic, social and aesthetic learning processes, and contribute to innovative processes connected to the school establishment.

\section{Improvisation and Exploration in Creative Processes}

The workshops in the Sounding Shakespeare project included a Performance and a Happening, and in both performances, improvisation was one of the components that drove the composition and interaction forward. As Steinsholt and Sommerro state, "improvisation is about being spontaneous and being able to contribute something that is not practiced or decided in advance (9, our translation). When improvising with others, you both take initiative and respond to others' input. In music, the tones and sounds work in the same way as words and text in verbal communication, and in our project, both text and music are improvised in an interaction. When 
improvising, it becomes important to "listen attentively" for this interaction to work. Ruud, a music therapist, highlights improvisation in his work with young adults, and he writes about "music meetings" characterized by participants falling into a common musical pulse, taking initiative and responding, creating, playing and experiencing tension and expectation together (42). In Sounding Shakespeare, we studied improvisation together with exploration to find out how the students experience the compositional performances with Shakespeare's words.

\section{Method}

\section{Collecting Data}

In the Sounding Shakespeare research project, we used the qualitative methodology Grounded Theory (GT). Through GT we have a flexible approach to finding concepts and core categories from our data (Corbin and Strauss; Charmaz). Our data comprise of questionnaires and video recordings of the final Performance and Happening. In the questionnaires, we asked how the participants experienced working with the assignment in each workshop. They were asked to focus on a) the progress, b) the collaboration, c) the creative process of composition and d) the final performances. We also asked them about their experience of interdisciplinary work with Music and English as subjects.

\section{Discussion of Findings}

One of the main findings from our study is that music can become a guiding agent for a more meaningful experience of a text. Our data show that the participants who worked with Shakespeare's text through music first (Group B) had a different experience of the text when working with the language in the second workshop than group A who worked with language first and then music. After composing a musical score to the excerpt in the first workshop, the participants in group B, when given a new excerpt in the second workshop, reported that the text had become "more alive"1 and that they had "internalised" the text. ${ }^{2}$ In contrast, the participants who worked on the Speech Composition first (group A) seemed more concerned with finding meaning in the text by analysing, interpreting and understanding it. One participant from this group stated that they "felt the focus (indirectly) was not only on the words but also on the interpretation and the mood in the text,"3 and another said their focus was to "interpret text and message." 
This shows that through music, the text feels more meaningful and alive. By reporting that the text "lives" and feels more "internalized," the participants are using embodied terms to describe their experiences of the text. Such embodied experience is what Stoltz notes as being the way we "“come to' an understanding of something from our point of view" (485) since our engagement with the world and how we learn and create meaning are not just cognitive or theoretical processes, they are also practical, aesthetic and affective (Stoltz; Dahl and Østern). Those who worked on the speech composition first, however, noted a stronger need for textual analysis or actual sense-making for each word when creating the music composition. These participants struggled with their music composition because of their concern with textual interpretation and analysis, and as Sloboda's model suggests, meaning-making in music and language are different in kind because the semantic level in music is less concrete (The Musical Mind 59). Thus, when the participants worked on the text first, they transferred this need for textual interpretation and understanding to their second workshop with music composition. This group encountered more challenges with the creative process since music cannot provide meaning in the same way as voice can (when reciting or singing the words).

Even though both groups experienced the text differently, they all reported focusing on the music of language in one way or other. Participants in Group B who started with musical composition, reported that they looked for a melody in the text and that the text had rhythm. One participant wrote that: "The text was very rhythmic, dynamic and it differed in theme in the different stanzas," 5 and another that the process was about "trying to put sounds and tones together to represent a text. ${ }^{, 6}$ Furthermore, several of the participants highlighted the musicality of the text: "words that were positive were given a positive timbre etc.,"7 and: "[we had to] come up with how we should place stress on words and the rhythm in the sentence." ${ }^{8}$ Further, it is clear from analysing the participants' performances that there are strong connections between the musical choices and the lyrics. Focusing on Sloboda's theories of phonemes and the music's pitch, frequency and duration, we can say that some phonemes often gain a high pitch. This is especially relevant to the phoneme /u/ in the words "you", "moon" and "rubies". This happens both in the voices and the sound of instruments during the Performance in workshop 1. Moreover, when the words are richly built up of consonants, such as "bush" and "fire", the presentation of the lyrics and music both have a rhythmic and repetitive motif of phonemes such as $/ \mathrm{g} /$ and $/ \mathrm{f} /$. 
When it comes to dynamics and rhythm, we saw a clear interaction in the musical character in both the Performance and Happening. The analysis of the recorded performances shows that there are some differences in the two workshops. In the Performance (workshop 1) the groups follow each other in dynamics, rhythm and the musical character. They agree on breaks, crescendo and decrescendo, glissandos and tonality or atonality and some words are more focused than others in both the Music and Speech Composition. However, the performance appears as a cohesive whole. The Happening (workshop 2) was more spontaneous because the groups played the composition together for the first time when we recorded it. The groups had not heard, nor talked about each other's compositions, before playing together. However, there were some interesting elements in the music that made it work as a complete composition. For example, a flute that plays a melody inspired by folk music in the middle and at the end of the composition, while a triangle, cymbals and percussion enhanced the content of the words. The Happening was both played in major tonality and atonality, and in this composition the students were more explorative and played the instruments in an untraditional technical way.

In both workshops, the students improvised their own graphic score. The music and the lyrics followed each other in the rhythm and the expression varied from a pulsing beat to glissando and crescendo. This follows Ruud's argument that music mediates interaction (43), and that the experience of creating, improvising and playing music together in particular moments leads to "music meetings" (42). In Sounding Shakespeare, this can be seen in parts of the music where the interaction feels complete, and where the text and the music follow each other closely in the performance.

The creative compositional process of the text is closely linked to the subject of music, where the focus is on improvisation, exploration and composition (Steinsholt and Sommerro; Ruud). When creating musical compositions in Sounding Shakespeare some students thought that it was demanding to find the many sound possibilities of the instruments: "to use the instruments' potential was challenging." Further, another participant stated that it was "more challenging and fun to work with music because we have to think about how to convey different feelings." 10 The individual explorative process with each instrument seemed to be both challenging and "fun" and it was "exciting to experiment freely."11 When it comes to collaboration some of the participants mentioned that when the assignment demanded a more open and free approach to the activity it felt more challenging, but that the collaboration in the 
group was better: "[we had a] closer collaboration in the group since we didn't get guidance,"12 "[I] experienced everyone as more participatory in workshop 2 with fewer guidelines"13 and "Workshop 2 required more collaboration because the assignment was freer."14 The participants' experiences of how to begin the process of composing and to find a musical form of the composition seemed to be more challenging in workshop 2 where the assignment was more open than in workshop 1. One participant stated that: "it was very hard to get started, maybe because it was so free." 15 Another participant said that it was "more difficult to find a form", ${ }^{16}$ and others ruminated on the process: "Should we play tonally, rhythmically, in high or low volume, when everything is allowed it can be difficult to decide on something concrete". ${ }^{17}$ However, one participant positively concluded that they "created music from where we thought the top/bottom points were and it actually sounded pretty good."18

To create music together seems to strengthen the collaboration in a creative process where there are greater challenges (workshop 2). Ruud also highlights the importance of feeling safe within a group to expressive creativity as a composer within the group. He states that a musical community is not solely about creating music, but about being accepted, seen, and confirmed in the interaction with music (Ruud 43). Some participants believed that the creative process was prevented by the fact that: "People with music experience dominated", ${ }^{19}$ and that was especially visible in Workshop 2. Steinsholt and Sommerro argue that in improvisation the tones and sounds communicate the same way as words do in a conversation (9). In a good conversation you need to take initiative and respond, and in the Sounding Shakespeare workshop the creative compositional process is based on improvisation. It is important to question whether it is possible to be a good improviser if you do not have musical expertise or training in playing an instrument. This is a relevant question in the project where members of the ensemble were not musically trained. Ruud refers to similar situations in his research where participants with no specific musical training improvise in a free and spontaneous way over a long time and that through this process, they receive important experiences of music. Through this means of exploration, musical highlights are encountered through meetings in music that connect the participants in a collaborative and collective situation (42). This is, according to Ruud, "the nature of improvisation" (42 our translation). The participants' experience of the Performance and Happening in Sounding Shakespeare all agree that they were both successful. It was surprising to most of them that the final performance went well: "thought it would be a crisis, but 
text and music fit together surprisingly well.," ${ }^{20}$ All in all, they seemed satisfied with their compositions and some of them favoured the experience of the Performance, and others the Happening.

Music-making is always dependent on collaboration between the musicians who are playing together. This is in contrast with literature's meaning-making, where the reader of a text creates meaning on their own, since reading often is an individual act. When misunderstandings occur, expressing such misunderstandings can be difficult. This has relevance to the classroom where pupils are expected to both encounter and read a variety of literary texts. We believe that by placing music composition at the heart of the learning process, pupils will experience Shakespeare in new and meaningful ways making working with his texts less fearful. In the students' reflections after the workshop, they expressed a strong displeasure in relation to their previous encounters with Shakespeare. One participant wrote that they used to hate Shakespeare, and another that "text analysis of [Shakespeare] [...] can kill motivation." ${ }^{21}$ However, in the final questionnaire, several students answered that after the workshop, they now find it easier to work with Shakespeare. One participant noted that they were more positive towards Shakespeare in this way, and that it was not "dry or boring as it used to be,"22 and another wrote that "I think it was surprisingly easy to work with Shakespeare's text in this workshop."23

\section{Conclusion}

Det var også spennende å finne en slags melodi i teksten. Nesten som å lete etter en sang som er gjemt $i$ en tekst. Det viste seg dessuten å vare veldig lett å finne den sangen. It was exciting to find some sort of melody in the text. Almost like looking for a song hidden in the text. It also became clear that finding that song was quite easy.

\section{Participant in Sounding Shakespeare}

To some extent, this participant summarizes the overarching questions of the Sounding Shakespeare project. Here, both music and text are highlighted in an active process of searching for meaning. This was also the main research question for our project: how can interdisciplinary approaches in English and Music contribute to meaningful experiences of Shakespeare's texts? Our main finding shows that music becomes an important guiding agent for experiencing text in a meaningful way. This can be transferred to all kinds of literary texts but is especially important 
when it comes to literature which is often branded as "difficult," like Shakespeare. The participants in our study all reported having negative previous experience with Shakespeare's texts, and that through the project they had received a new and more positive outlook on his work. The fact that Shakespeare's texts are seen as challenging is often due to language, and the struggle to understand can be caused by unfamiliar vocabulary, grammar, spelling and punctuation. When this is the case, finding new approaches to working with texts in the classroom becomes pivotal.

When the literary text is placed in a creative and aesthetic learning process, which includes musical composition and improvisation, the text is given meaning in collaboration with others, and perhaps this is also why the text feels lived. By performing the text, it no longer becomes just words on a paper, but words that are spoken, sung, and sounded out—words that are given melody, mood and, in this way, meaning. Our findings tell us that the participants found it easier to show and practice, instead of explaining with words the meaning of the text. In other words, we can say that music as a guiding agent is also a guide to creative activities for learning. In this way, the same strategies for active, explorative and aesthetic processes can be practiced in both music and in language learning. Our research has focused on the participants' experiences of Shakespeare's text, creating music and working interdisciplinary in aesthetic processes. Through the educational design of Sounding Shakespeare, we have found a new interdisciplinary approach to the subjects of English and Music by showing that music can be the guiding agent for a meaningful experience of text.

\section{Works Cited}

Bonde, Lars Ole. Musik og menneske: introduktion til musikpsykologi. Samfundslitteratur, 2009.

Charmaz, Kathy. Constructing Grounded Theory. Sage, 2014.

Corbin, Juliet, and Anselm Strauss. Basics for Qualitative Research. Sage Publications, 2015.

Core Curriculum - Values and Principles for Primary and Secondary Education. Ministry of

Education and Research, 4 Apr. 2019, https://www.regjeringen.no/contentassets/53d21ea2bc3a4202b86b83cfe82da93e/core-

curriculum.pdf. Accessed 21 May 2019.

Crystal, David. 'Think on my Words': Exploring Shakespeare's Language. Cambridge UP, 2008. 
Curriculum for Music. Norwegian Directorate for Education and Training, 1 Aug. 2006, http://data.udir.no/k106/rest_/MUS1-01.pdf?lang=eng. Accessed 29 May 2019.

Dahl, Thomas and Tone Pernille Østern. "Dybde//læring med overflate og dybde." Dybde//Laering: en flerfaglig, relasjonell og skapende tilnarming, edited by Tone Pernille Østern, Thomas Dahl, Alex Strømme, Jesper Aagaard Petersen, Anna-Lena Østern and Staffan Selander. Universitetsforlaget, 2019, pp. 39- 56.

Engh, Dwayne. "Why Use Music in English Language Learning? A Survey of the Literature." English Language Teaching, vol. 6, No. 2, 2013, pp. 113-127.

English Subject Curriculum. Norwegian Directorate for Education and Training, 1 Aug. 2013, http://data.udir.no/k106/rest/ENG1-03.pdf?lang=eng. Accessed 29 May 2019.

Gibson, Rex. Teaching Shakespeare. Cambridge UP, 1998.

"Happening." Britannica Academic, Encyclopædia Britannica, 11 Jul. 2019. academic.eb.com/levels/collegiate/article/Happening/435775. Accessed 14 Oct. 2019. Koelsch, Stefan. Brain and Music. Wiley, 2012.

Matz, Frauke and Michael Rogge. "Shakespeare in Shorts: A Multiliteracies Approach to Teaching Shakespeare". Shakespeare in the EFL Classroom, edited by Maria Eisenmann and Christina Lütge, Universitätsverlag WINTER, 2014, pp. 315-330.

McKenney, Susan E., and Thomas C. Reeves. Conducting Design Research. Routledge, 2012. Merleau-Ponty, Maurice. Phenomenology of perception, Routledge, 1945/2012.

Patel, Aniruddh D. Music, Language, and the Brain. Oxford UP, 2008.

Regulations Relating to the Framework Plan for Primary and Lower Secondary Teacher Education for Years 5-10. Ministry of Education and Research, 7 June 2016, https://www.regjeringen.no/contentassets/c454dbe313c1438b9a965e84cec47364/forskriftom-rammeplan-for-grunnskolelarerutdanning-for-trinn-5-10---engelsk-oversettelse.pdf.

Accessed 1 Oct 2018.

Ruud, Even. Musikk og identitet. 2nd ed., Universitetsforlaget, 2013.

Selander, Staffan. Didaktiken efter Vygostkij: design för lärande. Liber, 2017.

Shakespeare, William. A Midsummer Night's Dream. Ed. Linda Buckle. Cambridge UP, 2014. Sloboda, John A. Exploring the musical mind. Oxford UP, 2005.

---. The Musical Mind: The Cognitive Psychology of Music. Oxford UP, 1985. 
Steinsholt, Kjetil and Henning Sommerro. Improvisasjon: Kunsten å sette seg selv på spill. Damm, 2006.

Stoltz, Steven A. "Embodied Learning.” Educational Philosophy and Theory, vol. 47, No. 5, 2015, pp. 474-487.

Stredder, James. “Active Reading' - A Workshop on Reading Shakespeare's Text in Class”. Shakespeare in the EFL Classroom, edited by Maria Eisenmann and Christina Lütge, Universitätsverlag WINTER, 2014, pp. 243- 255.

Sæbø, Aud Berggraf. Drama som Laringsform. Universitetsforlaget, 2016.

Winston, Joe, and Tandy, Miles. Beginning Shakespeare 4-11. Routledge, 2012.

\section{Notes}

\footnotetext{
1 "The text becomes much more alive when made into a song" / "Teksten blir veldig mye mer levende når man gjorde den om til sang"

2 "I think that maybe I have internalised the text to a greater extent" / "Jeg tror kanskje jeg har internalisert teksten i større grad"

3 "Følte at fokuset (indirekte) ble ikke bare på ordene men og på tolkning og stemning i teksten"

4 "tolke tekst og budskap"

5 "Teksten var veldig rytmisk, dynamisk og differerte i tematikk i de ulike strofene"

6 "prøve å sette lyder og toner sammen for å representere en tekst"

7 "Ord som var positive fikk positiv klang osv."

8 "[vi måtte] tenke ut hvor vi skulle legge trykk på ordene og rytmen på setningen"

9 «Det var utfordrende å benytte instrumentenes potensiale»

10 «merutfordrende og gøy med musikk da man kan tenke hvordan man kan conveye ulike følelser»

11 «spennende å eksperimentere fritt»

12 «[vi hadde] tettere samarbeid på gruppa siden vi ikke fikk veiledning»

13 «[Jeg] opplevde alle som mer deltakende i workshop 2 med færre rammer»

14 «Workshop 2 krevde mer samarbeid pga frihet i arbeidet»

15 «Det var veldig vanskelig å komme i gang, kanskje fordi det var så fritt»

16 «vanskeligere å finne en form»

17 «Skulle vi spille tonalt, rytmisk, sterk eller svakt, når alt er lov kan det være vanskelig å bestemme seg for noe konkret»

18 «Lagde musikk utfra der vi trodde topp/bunnpunkt var og det stemte egentlig ganske bra»

19 «Folk med musikkerfaring dominerte»

20 "Trodde det skulle bli krise, men tekst og musikk passet overraskende bra sammen"

21 "tekstanalyser av [Shakespeare] kan drepe motivasjon"

22 "Ser mye lysere på å jobbe med Shakespeare nå på denne måten, ikke tørt og kjedelig som det har vært tidligere"

23 "Jeg synes det var overaskende enkelt å jobbe med Shakespeare-teksten i denne workshopen"
} 